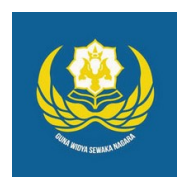

Jurnal Analogi Hukum

Journal Homepage: https://ejournal.warmadewa.ac.id/index.php/analogihukum

\title{
Wewenang Notaris Membuat Surat Kuasa Membebankan Hak Tanggungan (SKMHT) Menggunakan Blanko Yang Disediakan oleh Badan Pertanahan Republik Indonesia
}

\author{
Ni Made Arnita Sari*, I Nyoman Sumardika dan Ni Made Puspasutari Ujianti \\ Universitas Warmadewa, Denpasar-Bali, Indonesia \\ *arnitasari@gmail.com
}

\begin{abstract}
How To Cite:
Sari, N. M. A., Sumardika, I. N., \& Ujianti, N. M. P. (2021). Wewenang Notaris Membuat Surat Kuasa Membebankan Hak Tanggungan (SKMHT) Menggunakan Blanko Yang Disediakan oleh Badan Pertanahan Republik Indonesia. Jurnal Analogi Hukum. 3(1). 62-67. Doi: https://doi.org/10.22225/ah.3.1.3040.62-67
\end{abstract}

\begin{abstract}
A notary is a public official who is authorized to make authentic deeds, and one of his authorities is to make a Power of Attorney to Charge Mortgage Rights hereinafter referred to as SKMHT. The authority of a notary to be able to make SKMHT can be done by making his own notary deed that has been prepared by a notary issued by National Land Agency of the Republic of Indonesia. A notary is a public official whose sole authority is to make an authentic deed regarding all acts, agreements and stipulations required by a general regulation or by an interest desired to be stated in an authentic deed. The formulations of the problems used are: 1. Is the power of attorney to impose mortgage rights (SKMHT) made by a Notary using the form provided by the National Land Agency of the Republic of Indonesia is not an authentic deed? 2. What are the legal consequences if the power of attorney to impose mortgage rights (SKMHT) made by a notary using the form provided by the National Land Agency of the Republic of Indonesia? The research method used in this study is a type of normative legal research. The approach adopted to discuss the problems in this study is through the statute approach and the conceptual approach. So the Notary is authorized to make SKMHT as stipulated in Article 15 paragraph (1) UUHT, but if the SKMHT he uses the SKHMT form provided by the Republic of Indonesia BPN, then the SKHMT he made does not fulfill the provisions of Article 38 UUJN, so the SKMHT Deed he made is not Authentic Deed, but only in the form of Deed Under the Hand. As a result of the law if the SKMHT made by the Notary uses the SKHMT form provided by the Republic of Indonesia BPN, it will result in a Notary, SKMHT made by a Notary null and void.
\end{abstract}

Keywords: Authority; Notary; Authentic Act; Blanko.

\begin{abstract}
Abstrak-Notaris ialah pejabat umum yang berwenang untuk membuat akta otentik, dan salah satu kewenangannya adalah membuat Surat Kuasa Membebankan Hak Tanggungan selanjutnya disebut SKMHT. Wewenang seorang notaris ialah menerbitkan SKMHT dilaksanakan secara melahirkan akta notaris sendiri yang sudah diketik atau dipersiapkan oleh notaris yang di terbitkan Badan Pertanahan Nasional Republik Indonesia. Notaris menyandang pejabat umum yang memiliki wewenang dalam pembuatan akta otentik. Terkait segala tindakan, perjanjian serta penetapan yang diwajibkan pada peraturan umum atau oleh pihak yang mempunyai kaitan didahulukan dalam pernyataan akta otentik. Adapun rumusan masalah yang digunakan yaitu : 1. Apakah Surat Kuasa Membebankan Hak Tanggungan (SKMHT) yang dibuat oleh Notaris dengan menggunakan blanko yang disediakan oleh Badan Pertanahan Nasional Republik Indonesia bukan merupakan akta otentik?2. Bagaimanakah Akibat Hukum apabila Surat Kuasa Membebankan Hak Tanggungan (SKMHT) yang dibuat oleh Notaris menggunakan blanko yang disediakan oleh Badan Pertanahan Nasional Republik Indonesia? Metode penelitian yang dipergunakan pada penelitian ini jenis penelitian hukum normative. Pendekatan yang diterapkan pada penelitian ini ialah pendekatan UndangUndang dan pendekatan konseptual. Jadi Notaris berwenang menerbitkan SKMHT sesuai pada Pasal 15 ayat (1) UUHT, namun apabila SKMHT yang dibuatnya menggunakan blanko SKHMT yang disediakan oleh BPN RI, maka SKHMT yang dibuatnya tersebut tidak terlengkapinya Pasal 38 UUJN, sehingga Akta SKMHT yang dibuatnya bukan merupakan Akta Otentik, melainkan hanya berupa Akta Dibawah Tangan.Akibat hukum apabila SKMHT yang dibuat Notaris menggunakan blanko SKHMT yang disediakan oleh BPN RI, maka akan berakibat bagi Notaris, yaitu SKMHT yang dibuat Notaris batal demi hukum.
\end{abstract}


Kata Kunci: Wewenang; Notaris; Akta Otentik; Blanko

\section{Pendahuluan}

Undang-Undang telah mengatur Notaris ialah pejabat umum selaku yang menerbitkan akta otentik, serta salah satu kewenangannya mengeluarkan Surat Kuasa Membebankan Hak Tanggungan selanjutnya disebut SKMHT. Wewenang seorang notaris mampu menerbitkan SKMHT dilaksanakan dengan menerbitkan akta notaris sendiri yang sudah diketik maupun dipersiapkan oleh notaris yang dikeluarkan Badan Pertanahan Nasional Republik Indonesia. Kendati begitu, terkait isian blanko yaitu Surat Kuasa Membebankan Hak Tanggungan itu terdapat sesuatu tidak bersesuaian terhadap aturan pada Nomor 2 tahun 2014 tentang Perubahan atas UndangUndang Nomor 30 tahun 2004 tentang Jabatan Notaris (UUJN), menjadikan surat itu kelenyepan keotentisitasannya bilamana yang mengisikan blanko SKMHT ialah Notaris.

Diberlakukannya Undang-Undang Nomor 4 Tahun 1996 tentang Hak Tanggungan atas tanah beserta Benda-Benda yang mempunyai hubungan atas tanah(Lembaran Negara Republik Indonesia Tahun 1996 Nomor 42) ataupn disebut Undang-Undang Hak Tanggungan (UUHT), jadi Hak Tanggungan ialah kelembagan hak penjaminan terhdap tanah pada Hukum pertanah Nasional tertulis.

Notaris ialah jawatan umum dimana memiliki kewenangan dalam menerbitkan akta otentik tentang segala tindakan, persepakatan serta penentuan yang diwajibkan ketentuan umum atau dari yang mempunyai hubungan didahulukan untuk dituangkan pada akta otentik, terjaminnya kepastian tanggal, menyimpan aktanya serta mencantumkan grosse, salinan serta kutipan, seluruhnya selama penerbitan akta itu oleh peraturan umum tidak pula ditugaskan atau terkecualikan terhadap pejabat maupun pihak lain (Tobing, 1999).

Berdasarkan Pasal 15 (1) Undang-Undang Hak Tanggungan: " Surat Kuasa Membebankan Hak Tanggungan wajib dibuat dengan akta Notaris atau akta PPAt". Berkat terdapatnya aturan ini, jadi seorang notaris di emban wewenang oleh Undang-Undang dalam pembuatan SKMHT. Bersesuaian pada penjabaran Pasal 15 (1) UUHT tersebut maka wewenang notaris menerbitkan SKMHT bisa dilaksanakan atas penerbitan akta notaris ataupun atas penggunaan blanko akta sesuai dengan yang dikeluarkan oleh BPN-RI. Hal ini sejalan dengan hasil penelitian (Saprial, 2015) yang mengungkapkan Berdasarkan UUJN
Notaris sebagai Pejabat Umum memperoleh wewenang secara Atribusi, karena wewenang tersebut dicipatakan dan diberikan oleh UUJN, kemudian jika merujuk pada Pasal 15 ayat (1) UUHT, yang menyatakan bahwa SKMHT wajib dibuat dengan akta Notaris atau akta PPAT, hal ini berarti juga Notaris tersebut memperoleh wewenang secara Atribusi

Nantinya saat pengisian blanko suatu surat akta notaris diharuskan untuk diisi dengan lengkap dan sesuai dengan petunjuk yang telah disediakan, serta sesuai dengan apa yang diminta dalam peraturan tersebut terkait pengisian blanko. Blanko yaitu lembaran yang keadaannya masih kosong atau baru dimana lembaran itu harus diisi dengan data diri sehingga bisa diketahui dengan mudah pendataannya Notaris (UUJN) dijadikan panduan utama notaris pada pelaksanaan jabatan sehingga akta yang diterbitkan oleh notaris melengkapi syarat pada pernyataan selaku akta notaris yang memiliki ketentuan selaku akta otentik maka akhirnya tulisan surat yang diciptakan oleh notaris dapat berkedudukan sebagai akta otentik. Dalam hal ini SKMHT paling banyak digunakan oleh pihak bank yang berkedudukan menjadi kreditur. Wewenang seorang Notaris ialah untuk menerbitkanakta otentik. Atas aturan Pasal 1868 KUHPerdata, jadi satu di antara yang ada persyaratn supaya akta notaris bisa disebut menjadi akta otentik ialah bila akta itu dikeluarkan dalam bentuk yang ditetapkan Undang-Undang.

Pada penelitian sebelumnya, (Usman, 2018) mengungkapkan Notaris hanya berwenang membuat Akta Kuasa Membebankan Hak Tanggungan atau Kuasa Membebankan Hak Tanggungan, bukan membuat Surat Kuasa Membebankan Hak Tanggungan, apalagi harus menggunakan blangko/isian/formulir SKMHT sebagaimana ditetapkan dalam PMNA/PerKaban No. 3/1997 sebagaimana telah diubah dengan PerKaban No. 8/2012. Penelitian lainnya oleh (Iscahyani, 2010) mengungkapkan apabila akta SKMHT dibuat dihadapan Notaris, maka harus memperhatikan bentuk dan sifat akta Notaris (Pasal 38 ayat (1) UUJN) jo Pasal 1868 KUH Perdata. Bentuk SKMHT blanko BPN yang ditetapkan oleh lampiran 23 Pasal 96 ayat (1) huruf h Permenag/Ka. BPN No.3 Tahun 1997 dan angka 6 Surat Edaran Ka. BPN No. 3317/17.3-100/VIII/2009 tidak sinkron dengan 2 (dua) Undang-undang yaitu ketentuan Pasal 15 ayat (1) UUHT yang mewajibkan bahwa SKMHT wajib dibuat dengan akta Notaris dan 
ketentuan Pasal 38 UUJN tentang bentuk dan sifat akta Notaris

Di dasarkan uraian latar belakang tersebut diatas yang telah dibuat tersebut jadi bisa dirumuskan masalah sebagai berikut :

- Apakah Surat Kuasa Membebankan Hak Tanggungan (SKMHT) yang dibuat oleh Notaris dengan menggunakan blanko yang disediakan oleh Badan Pertanahan Nasional Republik Indonesia bukan merupakan akta otentik?

- Bagaimanakah Akibat Hukum apabila Surat Kuasa Membebankan Hak Tanggungan (SKMHT) yang dibuat oleh Notaris menggunakan blanko yang disediakan oleh Badan Pertanahan Nasional Republik Indonesia?

\section{Metode}

Pada penelitian ini mempergunakan penelitian hukum normatif oleh karenanya berawa atas konflik norma pada perundangundangan Republik Indonesia. Terdapatnya konflik norma pada penelitian ini berhubungan dengan bentuk blanko akta SKMHT yang di terbitkan oleh BPN-RI yang terdapat pada huruf h (lampiran 23) Pasal 96 ayat (1) Peraturan Menteri Negara Agraria/ Kepala Badan Pertanahan Nasional Nomor 3 tahun 1997, tidak sesuai dengan aturan yang ada pada UUJN, menjadikan tidak terpenuhinya blanko tersebut selaku blanko itu prosedur akta notaris.

Pada penelitian hukum normative ini, bahan pustaka ialah bahan dasar adalam ilmu penelitian yanng dikatakan bahan hukum sekunder, dasarnyabahan hukum dapat diklasifikasikan:

\section{- Bahan Hukum Primer}

Materi hukum yang menyandang dominasi, terdapat pada peraturan perndangundangan serta catatanresmi atapun risalah pada penerbitan peraturan perundang-undangan serta putusan hakim (Ali, 2009). Materi hukum primer disebut subjek-subjek hukum yang memiliki karakter memaksa dipergunakan pada perundang-undngan yang berlangsung di Indonesia.

\section{- Bahan Hukum Sekunder}

Pematerian hukum dimana memaparkan kejelasan terkait pematerian hukum primer (Sunggono, 2010). Pemateri hukum sekunder dipergunakan atas keterangan-katerangan ahli hukum, hasil investigasi hukum, hasil keilmuan golongan hukum. Pematerian hukum sekunder pada skripsi inilah ialah bacaan-bacaan terkait hukum perdata, hukum perjanjian akta, jabatan Notaris dan tulisan-tulisan yang berhubungan pada pembahasan.

\section{Hasil dan Pembahasan}

\section{Surat Kuasa Membebankan Hak Tanggungan (SKMHT) yang Dibuat oleh Notaris dengan Menggunakan Blanko yang Disediakan oleh BPN-RI Bukan Merupakan Akta Otentik}

Kewenangan ialah penguasaan kepada sekelompok orang tertentu ataupum penguasaan kepada aspek pemerintahan tertentu. Sedangkan wewenang hanyalah mengait sesuatu onderdil tertentu saja. Wewenang ialah perilaku hukum yang dimuat pada suatu jabatan didasarkan atas peraturan perundang-undangan yang bersesuaian mengenai jabatan yang berkaitan. Notaris ialah pejabat umum yang berkompeten menerbitkan akta otentik serta wewenanglain sesuai penjabaran UUJN. Nantinya agar suatu surat dapat dikatakan dan tergolong dalam pengertian akta maka surat tersebut haruslah tertandatangan.

Notaris selaku pejabat umum yang memiliki profesi hukum yang menyandang kedudukan strategis pada pembangunan Indonesia. Perjanjian, serta penetapan yang diwajibkan peraturan perundang-undangan atau yang didahuluka oleh yang berhubungan untuk dicantumkan pada akta otentik, menjaminkan kebenaran waktu penerbitan akta, menyimpankan akta, mencantumkan grosse, duplikat seeta kutipan akta,selama penerbitan akta itu tidak terkecualikan atas pejabat lain ataupu pihak lain yang ditunjuk undangundang.

Notaris ialah profesi yang menyandang keahlian khusus menuntut pengetahuan luas serta tanggung jawab yang berat untuk melayani kepentingan umum. Jabatan seorang pejabat negara atau pejabat umum diemban oleh notaris,. Bidang pekerjaan yang sengaja diterbitkan pada aturan hukum untuk kepentingn seta fungsi memiliki sifat berkesinambungan selaku suatu lingkungan pekerjaan tetap disebut dengan jabatan. Jadi tidak diperuntukan menerbitkan kuasa melaksanakan perubahan atas Hukum lainnya yang mempunyaimaksud membantu terjangkaunya berian penjaminan bersangkutan Misaklan tidak. Menerbitkan jangkauan untukdapat menjualkan, mennyewakan objek hak tanggungan, perpanjangkan hak atas, tanah atau untuk menguruspanjangkan sertifikat, 
mengganti nama dan sebagainya. Disetiap tulisan surat akta yang diciptakan notaris diharuskan memuat keterangan lengkap identitas penghadap oleh notaris, terhadap pengenalan dapat baik dilakukan dengan saksi maupun tidak dengan saksi pengenal.

Dalam Pasal 15 ayat (1) UUHT dijabarkan pemberian Hak Tanggungan diharskan dilaksanakan sendiri dari pemberi Hak Tanggungan dengan hadir di muka PPAT tetapi tidak dihadapan Notaris. Andaikata karena tidak mampu hadir sendiri di muka PPAT, dia haru menuding kelompok lainnya selaku kuasanya, atas Surat Kuasa Membebankan Hak Tanggungan (SKMHT) yang berpola Akta Otentik Pada Surat Kuasa Membebankan Hak Tanggungan ada 2 aspek yang harus terlihat, yakni :

\section{- Pemisahan isi atau inti dalam SKMHT}

Sangatlah jelas dibatasi oleh UUHT intinya ruang lingkup terhadapnya SKMHT, yakni hanyalah berisi perilaku Hukum membebankan Hak Tanggungan. Maka dari itu tidak diperkenankan menerbitkan kuasa melaksanakan perilaku Hukum lainnya, yang betujuan dalam memberi support atas dicapainya maksud pemberian jaminan yang terkait.

\section{- Penentuan Jangka Waktu}

Dalam melakukan pencegahan sepanjangpanjangnya diberikan kekuasaan erta terciptanya salahnyapenggunaan maupun supayaa terwujudnya kepastian hukum, maka diberlakukan SKMHT dibatasi jangka waktunya. Untuk hak atas Tanah yang telah tecatatnyaa, mengharuskan disertai APHT setelat-telatnya 1 (satu) bulan setelah dituangkan.

Mengikuti ketetapan-ketetapan yang berlaku maka demikianlah notaris adalah pejabat umum yang mengantongi wewenang untuk menerbitkan akta-akta otentik, terkait wujud dan prosedur, dari akata notaris tersebut harus sesuai dengan yang diatur dalam UUJN. Segenap hal yang berhubungan dengan Notaris di Indonesia di haruskan berpedoman pada UUJN. Jabatan Notaris ialah organisasi yang berada dibawah naungaan negara.

\section{Akibat Hukum Apabila Surat Kuasa Membebankan Hak Tanggungan (SKMHT) yang Dibuat oleh Notaris Menggunakan Blanko yang Disediakan Oleh BPN-RI}

Problema yang bangkit berkaitan atas otentisitas Surat Kuasa melimpahkan Hak Tanggungan akan sangat krusial, andaikata dihubungkan dengan Pemberian Hak Tanggungan yang diterbitkan atas dasar Surat Kuasa melimpahkan Hak Tanggungan yang cacat, kendati demikian Akta Pemberian Hak Tanggungannya sendiri menjelma cacat. Perseteruan yang nantinya dapat timbul terkait dengan otentisitas Surat Kuasa Membebankan Hak Tanggungan bisa jadi begitu kursial apabila dikaitkan dengan Pemberian Hak Tanggungan dimana surat itu terbuat atas dasar SKMHT yang cacat yang menyebabkan pula akta Pemberian Hak Tanggungannya jadi cacat. Keadaan inilah menjadi kekhawatiran semua pihak disebabkan atas cacatnya pada kasus ini dikarenakan tidak otentiknya akta pemberian hak tanggungan, sertifikat hak tanggungannya berubah jadi cacat, serta dengan cacatnya sertifikat hak tanggungan, serfikat hak tanggungan itulah tidak menyandang kekuatan eksekutorial, serta bahkan mampu menjadi hak tanggungannya sendiri tidak pernah ada.

Pada aturan hukum, pencantuman sanksi dijadikan suatu kewajiban, situasi ini disebabkan apabila suatu aturan hukum tidak terdapat sanksinya, maka sebuah peraturan hukum tidak akan mampu dijalankan serta tidak ada peran dan aksi dalam kaedah-kaedah hukum, andaikata kaedah-kaedah tersebut tidak mampu dipaksakan melalui sanksi serta menjalankan kaedah-kaedah yang dimaksudkan sesuai syarat ataupun hukum acara yang diberlakukan. Tanpa adanya suatu peraturan yang terkait tata cara jalannya sanksi perdata bagi notaris, adanya notaris selaku jabatan dimana memiliki bidang pekerjaan atau tugas akan memungkinkan interpretasi yang dikatakan pembuktian oleh akta notaris dimana kekuatan buktiannya hanya sebatas akta dibawah tangan dapat dilakukan secara sepihak tanpa melalui proses gugatan ke pengadilan.

Bilamana ketentuan tersebut dikaitkan dengan ketentuan Pasal 1 angka 7 UUJN yang menyebutkan : "Akta Notaris yang selanjutnya disebut akta adalah akta otentik yang dibuat oleh atau dihadapan notaris menurut bentuk dan tatacara yang diatur pada Undang-Undang ini”, akan bisa disimplkan yaitu akta notaris yang tidak sesuai rupanya terhadap ketentuan didalam UUJN, tidak dapat dipergunakan sebagai akta otentik. Dan akibat hukumnya adalah akta tersebut terbatas hanya berkekuatan sebatas akta bawahtangan dan di tandatangani oleh kedua pihak. Dengan kata lain, apabila SKMHT yang terberbentuk sebatas disesuaikan terhadap blanko yang disediakan oleh BPN-RI, maka SKMHT tidak bisa dikategorikan selaku 
akta otentik atau batal demi hukum karena tidak memenuhi ketentuan Pasal 38 UUJN sehingga hanya menyandang selaku akta dibawah tangan.

Notaris didalam penerbitan suatu kuasa melimpahkan dan juga menjatuhkan bebankan hak tanggungan tetap mempergunakan blanko SKMHT. Notaris tersebut mampu dikatakan sudah melakukan suatu tindakan diluar kewewenangannya sehingga SKMHT itu tak memiliki daya bukti selaku akta otentik tetapi hanya sebatas daya bukti akta dibawah tangan. Untuk itu Notaris berkompeten dapat menerbitkan akta Notaris, tapi ternyata mengeluarkan SKMHT, yang dapat dikatakan akta yang diciptakannya melampaui wewenangnya. Ketidakmampuan Notaris dalam menjalankan tugas Jabatan Notaris, dan menjadikan cetakan akta tersebut menjadi cacat, sorang yang memegang jabatan dapat dikatakan sebagai pejabat. Suatu jabatan tanpa pejabatnya, maka jabatan tersebut tidak dapat berjalan". maka apabila Notaris bertindak seperti itu pasti akan merugikan para pihak yang namanya tercantum didalam akta, dimana sebelumnya menjadi akta yang dinginkan berupa cetakan akta Notaris yang menyandang daya bukti sempurna. Prodak hukum oleh seorang notaris berupa surat atau dpat dikatakan berupa akta otentik dan tidak seluruh pejabat umum mempunyai wewenang dalam hal itu. Para pihak yang namanya ada pada akta mampu membuat pengajuan gugatan perdata ke pengadilan negri dan meminta Notaris yang terkait untuk dikenakan sanksi perdata yaitu berupa ganti uang terkait akta terhadap Notaris maka Notaris digugat oleh bank lewat perdata dikarenakan menerbitkan rupa akta yang daya buktinya sebatas cetakan surat dibawah tangan, terkait itu apabila seseorang pejabat notaris terbukti telah melakukan suatu tindakan yang bukan merupakan kewenangnnya, jadi pejabat itu dikatakan atau digolongkan telah melakukan satu perbuatan yang melanggar wewenang. Notaris tersebut mampu dikatakan sudah melakukan suatu tindakan diluar kewewenangannya sehingga SKMHT itu tak memiliki daya bukti selaku akta otentik tetapi hanya sebatas daya bukti akta dibawah tangan.

\section{Simpulan}

Berdasarkan uraian pembahasan yang telah dikemukakan, dapatlah ditarik kesimpulan yang mendasar pada kedua pokok permasalahan sebagai berikut :

Bahwa Notaris berwenang membuat SKMHT sebagaimana ketentuan Pasal 15 ayat (1) UUHT, namun apabila SKMHT yang dibuatnya menggunakan blanko SKHMT yang disediakan oleh BPN RI atau sesuai dengan Lampiran Perkaban No. 8 tahun 2012, maka SKHMT yang dibuatnya tersebut tidak memenuhi ketentuan Pasal 38 UUJN dan Pasal 1868 KUHPerdata, sehingga Akta SKMHT, yang dibuatnya bukan merupakan Akta Otentik, melainkan hanya berupa Akta Dibawah Tangan.

Akibat hukum apabila SKMHT yang dibuat Notaris menggunakan blanko SKHMT yang disediakan oleh BPN RI, maka akan berakibat bagi Notaris, yaitu SKMHT yang dibuat Notaris batal demi hukum, terdegradasi menjadi akta dibawah tangan dan tidak dapat dijadikan dasar dalam pembuatan APHT, sehingga Notaris nantinya bisa tertuntut agar mengganti keuangan, ganti rugi, denda dan sukubunga. Dan bagi Kreditor akan terancam untuk tidak memiliki hak sebagai kreditor konkuren yang mempunyai kekuatan eksekoturial terhadap obyek yang dijaminkan. Dan bagi Debitur akan berakibat yang terkait diperbolehkan membuat pengajuan untuk batal meminjam kreditannya kepada Kreditor.

Sehubungan adanya ketidak sesuaian antara peraturan yang satu dengan yang lainnya yang mengatur mengenai SKMHT, maka sangat diperlukan ketegasan dari pemerintah dalam menetapkan peraturan yang mengatur tentang SKMHT yang dibuat oleh Notaris agar tercipta keseragaman norma sesuai dengan lingkup kewenangan Notaris maupun PPAT.

Notaris tidak boleh mempergunkan lembarblanko SKMHT yang disediakan oleh BPN RI, sehingga dalam menjalankan jabatannnya tidak menyimpang dari materi SKMHT sesuai Undang-Undang Hak Tanggungan (UUHT) Nomor 4 Tahun 1996 tentang Hak Tanggungan atas Tanah Beserta Benda-Benda Yang Berkaitan Dengan Tanah dan bentuk SKMHT tetap berpedoman pada Pasal 38 Undang-Undang Republik Indonesia Nomor 2 Tahun 2014 tentang Perubahan atas Undang-Undang Nomor 30 Tahun 2004 tentang Jabatan Notaris (UUJN) .

\section{Daftar Pustaka}

Ali, H. Z. (2009). Metode Penelitian Hukum. Jakarta: Sinar Grafika.

Iscahyani, M. L. (2010). Kewenangan Notaris Membuat Akta Surat Kuasa Membebankan Hak Tanggungan (SKMHT). Universitas Brawijaya. Retrieved from http:// repository.ub.ac.id/156663/

Saprial, R. (2015). Kewenangan Notaris Untuk Membuat Surat Kuasa Membebankan 
Hak Tanggungan. Universitas

Airlangga. Retrieved from http://

repository.unair.ac.id/33736/

Sunggono, B. (2010). Metodelogi Penelitian Hukum. Jakarta: Rajawali Pers.

Tobing, G. H. L. (1999). Peraturan Jabatan Notaris, Cetakan kelima. Jakarta: Erlangga.

Usman, R. (2018). Kewenangan Notaris Dalam Membuat Surat Kuasa Membebankan Hak Tanggungan Dengan Akta. Jurnal Legislasi Indonesia, 15(3). Retrieved from https://e-jurnal.peraturan.go.id/ index.php/jli/article/view/222 